\title{
Bacterial isolates from bryozoan Pleurocodonellina sp.: Diversity and antimicrobial potential against pathogenic bacteria
}

\author{
MEEZAN ARDHANU ASAGABALDAN ${ }^{1, \vartheta}$, GILLES BEDOUX ${ }^{2}$, NATHALIE BOURGOUGNON ${ }^{2}$, RHESI \\ KRISTIANA ${ }^{1}$, DIAH AYUNINGRUM ${ }^{3}$, AGUS SABDONO ${ }^{4}$, AGUS TRIANTO ${ }^{4}$, OCKY KARNA RADJASA ${ }^{4,5}$ \\ ${ }^{1}$ Department of Coastal Resources Management, Faculty of Fisheries and Marine Science, Universitas Diponegoro. Jl. Imam Bardjo, SH, No. 15, \\ Semarang 50241, Central Java, Indonesia.Tel.: +62-24-7474698, Fax.: +62-24-7474698, `email: asagabaldan.id@ gmail.com \\ ${ }^{2}$ Laboratoire de Biotechnologie et Chimie Marines, Universite de Bretagne-Sud, EA 3884, LBCM, IUEM, F-56000 Vannes, France \\ ${ }^{3}$ Department of Aquatic Resources Management, Faculty of Fisheries and Marine Science, Universitas Diponegoro. Jl. Imam Bardjo, SH, No. 15, \\ Semarang 50241, Central Java, Indonesia \\ ${ }^{4}$ Department of Marine Science, Faculty of Fisheries and Marine Science, Universitas Diponegoro.Jl. Prof. Soedarto, SH, Tembalang, Semarang50275, \\ Central Java, Indonesia \\ ${ }^{5}$ The Ministry of Research and Public Services at Ministry of Research, Technology and Higher Education, Indonesia
}

Manuscript received: 22 July 2019. Revision accepted: 15 August 2019.

\begin{abstract}
Asagabaldan MA, Bedoux G, Bourgougnon N, Kristiana R, Ayuningrum D, Sabdono A, Trianto A, Radjasa OK. 2019. Bacterial isolates from bryozoan Pleurocodonellina sp.: Diversity and antimicrobial potential against pathogenic bacteria. Biodiversitas 20: 2528-2535. There is an urgent need to discover new compounds with antibacterial activity, which can be developed into lead structures for the treatment of human disease caused by multidrug-resistant (MDR) bacteria. In this study, we focussed on bryozoan-associated bacteria to screen them toward antibacterial activities, since the microbiome of these organisms can still be regarded as underinvestigated. Most of the few publications about bryozoan-associated bacteria focused on taxonomy and the potential as producers of antibacterial natural products were neglected. Four specimens of bryozoan Pleurocodonellina sp. were collected from Teluk Awur, Jepara in Java Sea, Indonesia. Therefrom, 56 bacterial strains were isolated, and 17 displayed antibacterial activities against MDR bacteria Pseudomonas aruginosa, Klebsiella pneumoniae, Acinetobacter baumannii, Enterobacter cloacae, and methicillin-resistant Staphylococcus aureus (MRSA). Taxonomic identification of the bacteria by $16 \mathrm{~S}$ rRNA gene sequencing revealed them belonging to the genera Virgibacillus, Pseudoalteromonas, Halomonas, and Bacillus. Most interestingly, the genus Virgibacillus was dominantly obtained from the Pleurocodonellina sp. specimens, i.e., 12 active isolates. Nevertheless, the best activities against MDR bacteria (both Gram-positive and Gram-negative) were contributed to isolates showing $>99 \%$ identity to Pseudoalteromonas. The results further suggest adding the genus Virgibacillus as bacteria associated with bryozoan, since to the best of our knowledge there were no reports of this genus isolated from bryozoan.
\end{abstract}

Keywords: Associated-bacteria, bryozoan, Pleurocodonellina, multi-drug resistant, Virgibacillus

\section{INTRODUCTION}

Human diseases that are caused by bacterial infections become a thorough concern for medical management because they are difficult to control with antibiotics (Guiton et al. 2010). These pathogenic bacteria have the ability to resist up to three or more classes of antibiotics (multidrug-resistant) or even to resist all classes of antibiotics (pan drug-resistant). Hence, they can adapt and outgrow in their environment with the presence of antibiotics (Lister et al. 2009). Center for Disease Control and Prevention (CDC) has reported there are several problematic multidrug-resistant bacteria encountered today such as Extended-spectrum beta-lactamases (ESBL) Escherichia coli, MDR Acinetobacter baumannii, Pseudomonas aeruginosa, and Klebsiella pneumoniae represent the gram-negative bacteria and methicillinresistant Staphylococcus aureus (MRSA), vancomycinresistant Enterococcus spp. and MDR Streptococcus pneumoniae for the gram-positive bacteria (Sabuda et al 2008; CDC 2013). Both of them have serious health threats in many hospitals because of the significant risks.
Moreover, other studies reported that there is a connection between the presence of multi-drug-resistant pathogenic bacteria and the diseases that are caused by them, made increasing morbidity and mortality, higher hospital costs, and increasing length of hospital stay (Kerr and Snelling 2009; Mauldin et al. 2010; Tumbarello et al. 2011). This urgent matter makes scientists have been charged to find new antibiotics to overcome the pathogenic bacteria that have the multidrug-resistant ability.

Marine organisms include sponges, corals, algae, tunicates, and others have attracted the attention of many scientists for the last decades due to their bioactive compounds (Sharp et al. 2007). Marine organisms as natural resources produce diverse potential bioactive compounds and some of them are highly effective against human pathogens (Thakur et al. 2005; Blunt et al. 2010, 2015). In spite of sponges and cnidarians are the highest contributors for the compounds used in pharmaceuticals and drug developments, there is one of marine organisms that is not well noticed for its bioactive compounds as future potential for drugs. The less-noticed organism comes 
from the bryozoan whereas it contributes only $1 \%$ of all marine natural products (Blunt et al. 2010).

Bryozoans characterized as sessile colonial and mostly found in marine environment, though, some of them can be found in freshwater environment. The body consists of a polyp, protected by a gelatinous or calcareous box termed a zooid and many zooids assembly to form the colony. Bryozoan is filter-feeders and the food is collected via lophophore (ciliated tentacles). Reproduction occurs sexually (dispersive larval stage), or by asexual (fission of colony fragments). They settle on surfaces either living things or non-living hard substrates. Marine bryozoans can adapt and grow on other micro-organisms, such as mussels, algae, and corals (Ryland 2005). Recently, bryozoans become a part of natural resources that contribute to the discovery of new bioactive compounds. Nevertheless, most of the bryozoan studies concern about the fossil-revealed (Heindl et al. 2010). Sharp et al. (2007) reported that about 200 chemical structures of bryozoan metabolites have been discovered from 1980 to 2006 including terpenes, peptide, macrolides, alkaloids, etc. In fact, even though there are more than 8000 species of bryozoans have been recorded (Ryland 2005; Massard and Geimer 2008), only 32 species had been reported producing bioactive compounds. These reports showed that the exploration and investigation of natural products from bryozoan group are scarce. The complexity of bryozoan taxonomic could be the main reason for the low diversity of bryozoan species. Only bryozoan species characterized by their large form, which make them easy to recognize and are abundant, has been extensively studied regarding their bioactive compound.

Bryostatin is one of the most promising bioactive compounds coming from bryozoan Bugula neritina, can inhibit the performance of leukemia cancer cells. The isolated and purified of bryostatins called as bryostatin 1 and 2 have been known for their anti-leukemic properties and another cytotoxicity (Pettit et al. 1982; Lopanik et al. 2004; Yu et al. 2015). Nevertheless, it needs a substantial amount of biomass to obtain the target compound, for example, 13 tons of $B$. neritina was required to obtain $13 \mathrm{~g}$ of bryostatin 1 (Schaufelberger et al. 1991).

Several studies reported that many natural products from marine macroorganisms are resemblance to their associated microbial (bacteria, fungi, etc.) and these associated microbial could be the real producers of those compounds (Anthoni et al. 1990; Peters et al. 2002; König et al. 2006). Davidson et al. (2001) have reported that the true producer of bryostatin compounds from $B$. neritina was the microbial symbiont "Candidatus Endobugula sertula'. Another report regarding alkaloids from bryozoan Amathia wilsoni, amathamide, has shown that associated bacteria became a microbial origin of that compound (Walls et al. 1995). Those reports become one of promising way to overcome the over-exploitation of bryozoan materials. Nevertheless, studies on the bryozoan-associated bacteria are still scarce. The latest report has published that bacteria associated with marine bryozoan, Membranipora membranacea have a potential antibacterial activity (Heindl et al. 2012).
The study of bryozoan in Indonesia is not as comprehensive as other marine organisms and is still scarcely exist. The latest research of bryozoan in Indonesia was about the diversity of bryozoan by fossil approaches (Di Martino et al. 2015; Di Martino and Taylor 2015, 2018). In this study, four specimens of bryozoan Pleurocodonellina sp. were collected from the Java Sea. More than 50 associated bacteria were successfully cultivated and their antibacterial activities were assessed. Isolates showing antibacterial potential were phylogenetically classified by $16 \mathrm{~S}$ rRNA gene sequencing.

\section{MATERIALS AND METHODS}

\section{Sample collection of bryozoans Pleurocodonellina sp.}

Sampling times and sites in the Java Sea were chosen at Teluk Awur, Jepara, Central Java, Indonesia as follows: 19 September 2017, 06³6'59.20"S, 110³8'19.60"E; sampling depth $2 \mathrm{~m}$ (Pleurocodonellina I) and 21 September 2017, 06 ${ }^{\circ} 37^{\prime} 00.46^{\prime \prime S}, 110^{\circ} 38^{\prime} 20.73 " \mathrm{E}$; $1,5 \mathrm{~m}$ (Pleurocodonellina II) (Figure 1). Samples were collected by snorkeling. The collected bryozoans were put into sterile plastic bags underwater to avoid contact with air, stored in local seawater, and brought to the laboratory under the coolerbox $\left(4^{\circ} \mathrm{C}\right)$ for further treatment.

\section{Scanning electron microscopy (SEM) of bryozoan surfaces}

Pleurocodonellina sp. samples were fixed with $3 \%$ (v/v) glutaraldehyde in phosphate buffer saline (PBS). Bryozoan materials were washed with PBS three times before further preparations. Samples were dehydrated with gradient ethanol series $(30 \%, 50 \%, 70 \%, 90 \%$, and $100 \%$; v/v) and sputter-coated with gold film of approximately 11$15 \mathrm{~nm}$ thickness (Edwards SC06). Samples were examined with scanning electron microscope at 15-20 KV (Jeol JSM6460LV, JEOL, USA) and pictures were stored digitally and processed using JSM Software (JEOL, USA).

\section{Isolation of bryozoan associated bacteria}

Samples were processed under aseptic conditions as follows: 1 gr of bryozoans were rinsed with sterile seawater, macerated with sterile micro-pestle and homogenized with $1 \mathrm{~mL}$ sterile natural seawater at room temperature (RT, $24 \pm 2^{\circ} \mathrm{C}$ ). The homogenized samples were serially diluted and spread $(30 \mu \mathrm{L})$ on minimal media, contained $0.25 \%(\mathrm{w} / \mathrm{v})$ of peptone (Oxoid), $0.05 \%(\mathrm{w} / \mathrm{v})$ of yeast extract (Oxoid), and 1.5\% (w/v) of agar (Oxoid), dissolved in sterile natural seawater and incubated at room temperature (RT, $24 \pm 2^{\circ} \mathrm{C}$ ) up to 1 week. Colonies were picked and purified by making streak plates based on the morphological features (Madigan et al. 2015). The strains of associated bacteria were named with the initials of bryozoan from which they were isolated. Colonies with different morphological characteristics were picked up and transferred onto freshly prepared media containing the same ingredients as before until pure cultures were obtained. 


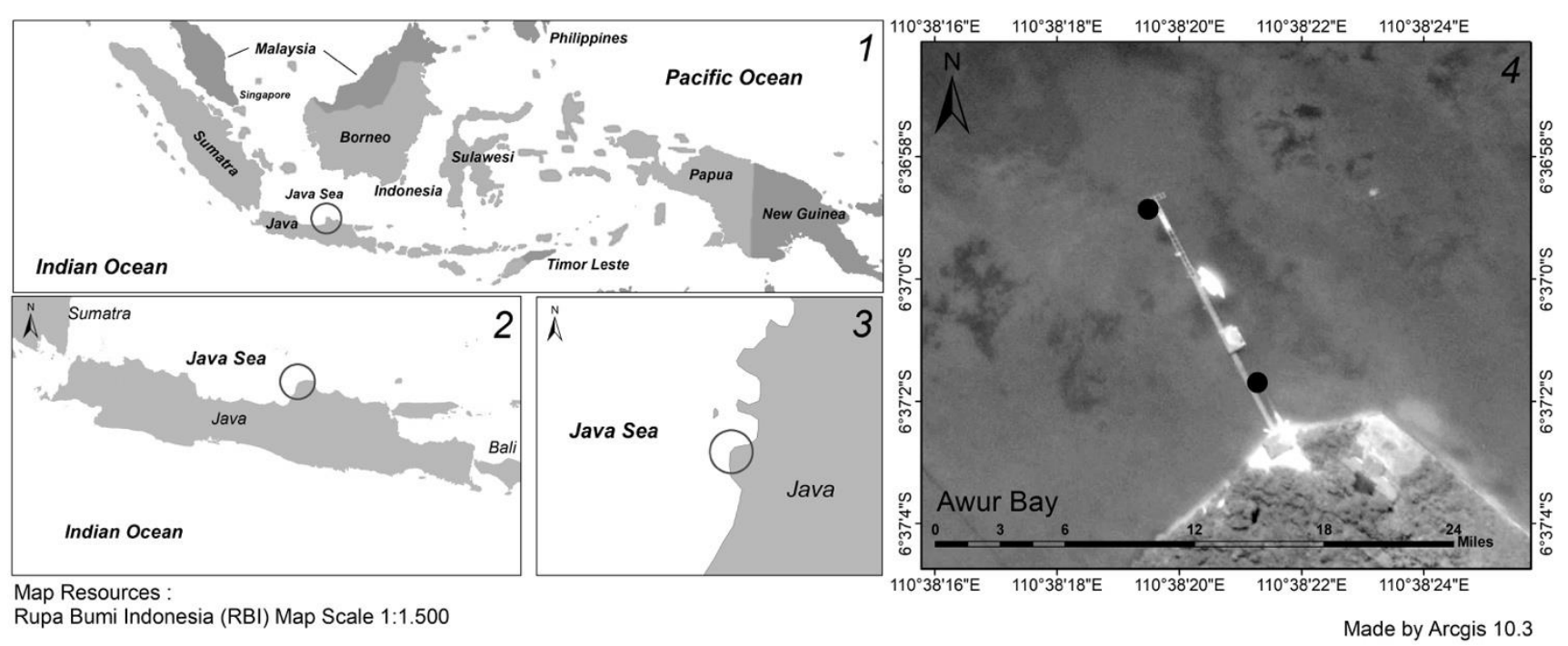

Figure 1. Map of the study areas in the Java Sea, central Indonesian Archipelago. 1-3, study localities on the island of Java indicated by black circles at increasing scales. Bryozoans were collected at two sampling sites (black dots) in Teluk Awur (4)

\section{Screening for antibacterial activities against MDR bacteria}

Pure cultures were inoculated approximately $1 \mathrm{~cm}^{2}$ (small dots) on minimal media in triplicate. After growing (depend on the growth rate this was usually $1-7$ days) the plates were covered with Nutrient soft agar $(0.3 \%(\mathrm{w} / \mathrm{v})$ nutrient broth, $1 \%(\mathrm{w} / \mathrm{v}) \mathrm{NaCl}$ and $0.7 \%$ (w/v) agar) containing one of the indicator strains with concentration was 0,5 McFarland. Following strains were used for antibacterial testing: multi-drug resistant (MDR) Pseudomonas aeruginosa (Pa), Klebsiella pneumoniae $(K p)$, Acinetobacter baumannii (Ab), and Enterobacter cloacae $(E c)$ for Gram-negative and methicilin-resistant Staphylococcus aureus (MRSA) for Gram-positive that were obtained from the Medical Microbiology Laboratory of Dr. Kariadi Central Hospitals, Semarang, Central Java, Indonesia. The plates were incubated at optimum temperature for bacterial growth $\left(37 \pm 2^{\circ} \mathrm{C}\right)$ for $24 \mathrm{~h}$. The antibacterial activity of MDR bacteria was defined by the presence of clear zones around the bacteria isolates. Levels of activity (without isolates) were categorized as follows: no effect (-), 0-1 mm (+), 1-3 mm (++), 3-7 mm (+++) and 7-15 mm (++++).

\section{S rRNA gene sequence-based identification of active bacteria}

The molecular-based works were carried out at Laboratory of Tropical Marine Biotechnology, Diponegoro University, Semarang, Indonesia. Genomic DNA was extracted using Chelex 100-based methods (Ayuningrum et al. 2017) and purified from the pure culture of potential bacteria for PCR. The primer pair $27 \mathrm{f}\left(5^{\prime}-\right.$ AGAGTTTGATCCTGGCTCAG-3') and 1492r (5'GGTTACCTTGTTACGACTT-3') were used for amplification of the 16S rDNA sequences (Lane, 1991). The PCR reactions were conducted as follows: initial denaturation at $95^{\circ} \mathrm{C}$ for $3 \mathrm{~min}, 30$ cycles of amplification (each cycle consisting of denaturation at $94^{\circ} \mathrm{C}$ for $1 \mathrm{~min}$, annealing at $55^{\circ} \mathrm{C}$ for $1 \mathrm{~min}$, and extension at $72^{\circ} \mathrm{C}$ for 1 $\min$ ). A final extension was performed at $72^{\circ} \mathrm{C}$ for $7 \mathrm{~min}$. The PCR products were verified by agarose (1\%) gel electrophoresis and the digital images were obtained using UVI Doc HD5 (UVITEC Cambridge). The PCR product purifications, as well as sequencing, were undertaken at the Molecular Biology Laboratory, Agency for the Assessment and Application Technology (BPPT), Jakarta, Indonesia. Results were compared with other sequences in the NCBI prokaryotes database using BLAST. The phylogenetic tree of sequence results was constructed by the maximumlikelihood analysis and bootstrap values were also performed using the program MEGA 7.0 (Tamura et al. 2007). The 16S rRNA gene sequences were submitted to the NCBI gene bank databases with the accession numbers MN096861 to MN096879.

\section{RESULTS AND DISCUSSION}

\section{Sample collection of bryozoans Pleurocodonellina sp.}

Encrusting bryozoans Pleurocodonellina sp., were collected from the Teluk Awur, Jepara, were identified by morphology (morpho-species). The characteristics of this genus are distinguished by the shape of the orificial sinus; the shape and orientation of the avicularia; and the number of pores on the ovicell. This species has calcified frontal shield. Primary orifice was subcircular in outline, wider than long. The sinus made U-shaped, subrounded in shape, flanked by two sharp condyles with serrated tips. Most autozooids have a single adventitious avicularium placed proximolateral to orifice and directed proximally. Ovicell of this species was prominent, globular, and wider than long, with the pores was approximately 38-43.

Each site obtained a different number of colony (Table 1). They strongly-attached on mussels and rocks, patched up to a diameter $20 \mathrm{~mm}$ (Figure 2). 


\section{Scanning electron microscopy (SEM) of bryozoan surfaces}

Zooids (up to thousands) may pattern-form one colony of the Pleurocodonellina sp. and each zooid has a single orifice with avicularia as features (Figure 3A). Some of the membrane (operculum) that covers the orifice broke open due to sample preparation. Bacteria could be found on the surfaces of the samples but not all the parts of the colony are covered. Bacteria colonization were detected on the lateral part of the avicularia. In contrast, avicularia that active part of colony was apparently not colonized by any microorganisms (Figure 3B). Bacteria covered the zooid (arrows) but lack of bacteria colonization on the orifice (or) and avicularia (av) parts (Figure 3C). The proximal part of avicularia showed a little colonization of bacteria while the distal part was not colonized (Figure 3D).

\section{Isolation of bryozoan-associated bacteria and antibacterial activities}

The total of 56 strains was selected for isolation of pure cultures according to colony morphology and color from each dilution series and two sampling sites (Table 1). Approximately 30\% (17 isolates) of the total isolates showed inhibitory activities against MDR bacteria, at least one indicator strain (Table 2). MDR bacteria $\mathrm{Pa}$ was inhibited by $59 \%, K p$ by $12 \%, A b$ by $18 \%, E c$ by $53 \%$, and MRSA by $48 \%$ of all active isolates. Among these active strains, five isolates $(30 \%)$ displayed inhibition both Gramnegative and Gram-positive MDR bacteria. The highest counts of active bacteria were belonged to the Virgibacillus genera, since 12 out of 17 isolates (70\%) displayed antibiotic activities (Table 2).

Twelve isolates of Virgibacillus-related isolates demonstrated inhibition of all MDR bacteria with different activities. On the other hand, Bacillus-related isolates TAB02-17 and TAB05-15 only suppressed growth of Gram-negative bacteria except for MDR $K p$. Antibacterial test of Halomonas-related isolates between TAB03-4 and TAB06-5 displayed inhibition of both MDR E. cloacae and MRSA. Those each isolates have different host and location but same antibacterial activities.

Interestingly, only Pseudoalteromonas-related isolate TAB03-6 exclusively inhibited the growth of majority of MDR bacteria with the highest zone of inhibition. $P$. piscicida isolates TAB03-6 displayed the highest inhibition of MDR $P$. aeruginosa and MRSA and also inhibited the growth of MDR $K p$ and $E c$ with lower activities.

\section{S rDNA sequence-based phylogenetic analysis of bioactive bacteria}

A total of 17 strains with antibacterial activity against MDR bacteria were classified phylogenetically (Figure 4). The majority of the active isolates belonged to Virgibacillus genera (70\%). The following genera of active bacteria belonged to Bacillus (12\%), Halomonas (12\%) and Pseudoalteromonas (6\%). The genus Virgibacillus was being isolated from all four bryozoan samples. Interestingly, three different isolates (Virgibacillus, Pseudoalteromonas, Halomonas) were only obtained from bryozoan Pleurocodonellina sp. samples TAB03.
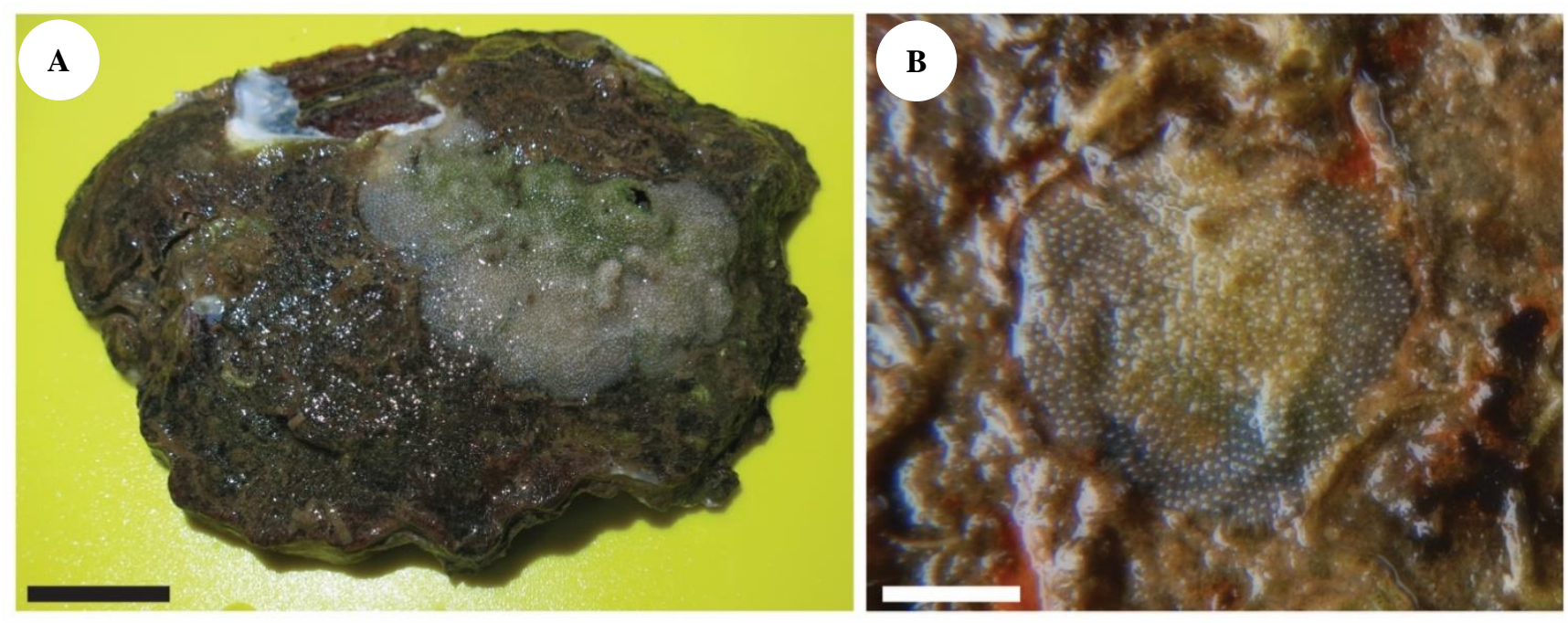

Figure 2. Pictures of bryozoan Pleurocodonellina sp. (A) Samples attached on the surface of mussels (arrow); and on rocks, making one of pattern-form colony (B). Scale bars: (A) $10 \mathrm{~mm}$; (B) scale: $5 \mathrm{~mm}$

Table 1. Classification of sampling sites and number of bacteria isolated from bryozoan Pleurocodonellina sp.

\begin{tabular}{|c|c|c|c|c|}
\hline Sampling date & Sampling site & Number of colony(s) & Sample ID & Number of isolated bacteria \\
\hline $\begin{array}{l}\text { 2017-09-19 } \\
\text { (Pleurocodonellina I) }\end{array}$ & $\begin{array}{l}06^{\circ} 36 ' 59.20^{\prime \prime} \mathrm{S} \\
110^{\circ} 38^{\prime} 19.60^{\prime \prime} \mathrm{E}\end{array}$ & 3 & $\begin{array}{l}\text { TAB02 } \\
\text { TAB03 } \\
\text { TAB05 }\end{array}$ & $\begin{array}{l}17 \\
10 \\
15\end{array}$ \\
\hline $\begin{array}{l}\text { 2017-09-21 } \\
\text { (Pleurocodonellina II) } \\
\text { Total }\end{array}$ & $\begin{array}{l}06^{\circ} 37^{\prime} 00.46^{\prime \prime} \mathrm{S} \\
110^{\circ} 38^{\prime} 20.73 " \mathrm{E}\end{array}$ & 1 & TAB06 & $\begin{array}{l}14 \\
56 \\
\end{array}$ \\
\hline
\end{tabular}


Table 2. 16S rDNA-based sequence similarity (BLAST) and antibacterial activities of isolates

\begin{tabular}{|c|c|c|c|c|c|c|c|c|c|}
\hline \multirow{2}{*}{ Isolates } & \multirow{2}{*}{ Nearest phylogenetic neighbor } & \multirow{2}{*}{$\begin{array}{l}\text { Base- } \\
\text { pairs }\end{array}$} & \multirow{2}{*}{$\begin{array}{c}\text { Similarity } \\
(\%)\end{array}$} & \multirow{2}{*}{$\begin{array}{c}\text { Accession } \\
\text { Number }\end{array}$} & \multicolumn{5}{|c|}{ anti-MDR activity $^{(\mathrm{a}, \mathrm{b})}$} \\
\hline & & & & & $\mathbf{P a}$ & Kp & $\mathbf{A b}$ & Ec & MRSA \\
\hline TAB02-3 & Virgibacillus salarius SA-Vb1 & 1437 & 98.9 & MN096872 & - & - & - & ++ & - \\
\hline ТАВ02-8 & Virgibacillus salarius $\mathrm{SA}-\mathrm{Vb} 1$ & 1416 & 99.7 & MN096873 & + & - & + & - & ++ \\
\hline TAB02-10 & Virgibacillus salarius $\mathrm{SA}-\mathrm{Vb} 1$ & 1051 & 97.4 & MN096870 & ++ & - & - & - & - \\
\hline TAB $02-13$ & Virgibacillus salarius 123 & 1450 & 96.5 & MN096871 & + & - & - & - & + \\
\hline TAB02-17 & Bacillus stratosphericus $41 \mathrm{KF} 2 \mathrm{a}$ & 1420 & 99.9 & MN096861 & + & - & - & + & - \\
\hline TAB03-1 & Virgibacillus salarius $\mathrm{SA}-\mathrm{Vb} 1$ & 1437 & 99.6 & MN096862 & ++ & - & - & + & - \\
\hline TAB03-4 & Halomonas axialensis Althf1 & 1403 & 99.6 & MN096863 & - & - & - & + & + \\
\hline TAB03-6 & Pseudoalteromonas piscicida NBRC 103038 & 1385 & 99.7 & MN096877 & +++ & + & - & ++ & +++ \\
\hline TAB03-10 & Virgibacillus salarius $\mathrm{SA}-\mathrm{Vb} 1$ & 628 & 94.8 & MN096864 & - & - & - & - & ++ \\
\hline TAB05-2 & Virgibacillus salarius $\mathrm{SA}-\mathrm{Vb} 1$ & 1439 & 99.7 & MN096865 & + & - & - & ++ & - \\
\hline TAB05-6 & Virgibacillus salarius $\mathrm{SA}-\mathrm{Vb} 1$ & 1450 & 99.6 & MN096876 & ++ & - & - & - & - \\
\hline TAB05-8 & Virgibacillus salarius $\mathrm{SA}-\mathrm{Vb} 1$ & 1065 & 99.9 & MN096866 & - & - & - & - & ++ \\
\hline TAB $05-15$ & Bacillus paramycoides MCCC $1 A 04098$ & 1411 & 98.2 & MN096867 & - & - & + & + & - \\
\hline TAB06-5 & Halomonas axialensis Althf1 & 1403 & 99.7 & MN096869 & - & - & - & + & + \\
\hline TAB06-7 & Virgibacillus marismortui 123 & 1434 & 98.8 & MN096875 & + & - & + & - & - \\
\hline TAB06-13 & Virgibacillus salarius SA-Vb1 & 1450 & 99.7 & MN096868 & + & + & - & - & - \\
\hline TAB06-14 & Virgibacillus marismortui 123 & 968 & 99.9 & MN096874 & - & - & - & ++ & - \\
\hline
\end{tabular}

Note: ${ }^{a}$ MDR, Multidrug resistant bacteria; Pa, Pseudomonas aeruginosa; Kp, Klebsiella pneumoniae; Ab, Acinetobacter baumannii; Ec, Enterbacter cloacae; MRSA, Methicilin-resistant Staphylococcus aureus. ${ }^{\mathrm{b}}$ Inhibition zone for antibacterial activity: -, no effect; +, 0$1 \mathrm{~mm} ;++, 1-3 \mathrm{~mm} ;+++, 3-7 \mathrm{~mm} ;++++, 7-12 \mathrm{~mm}$
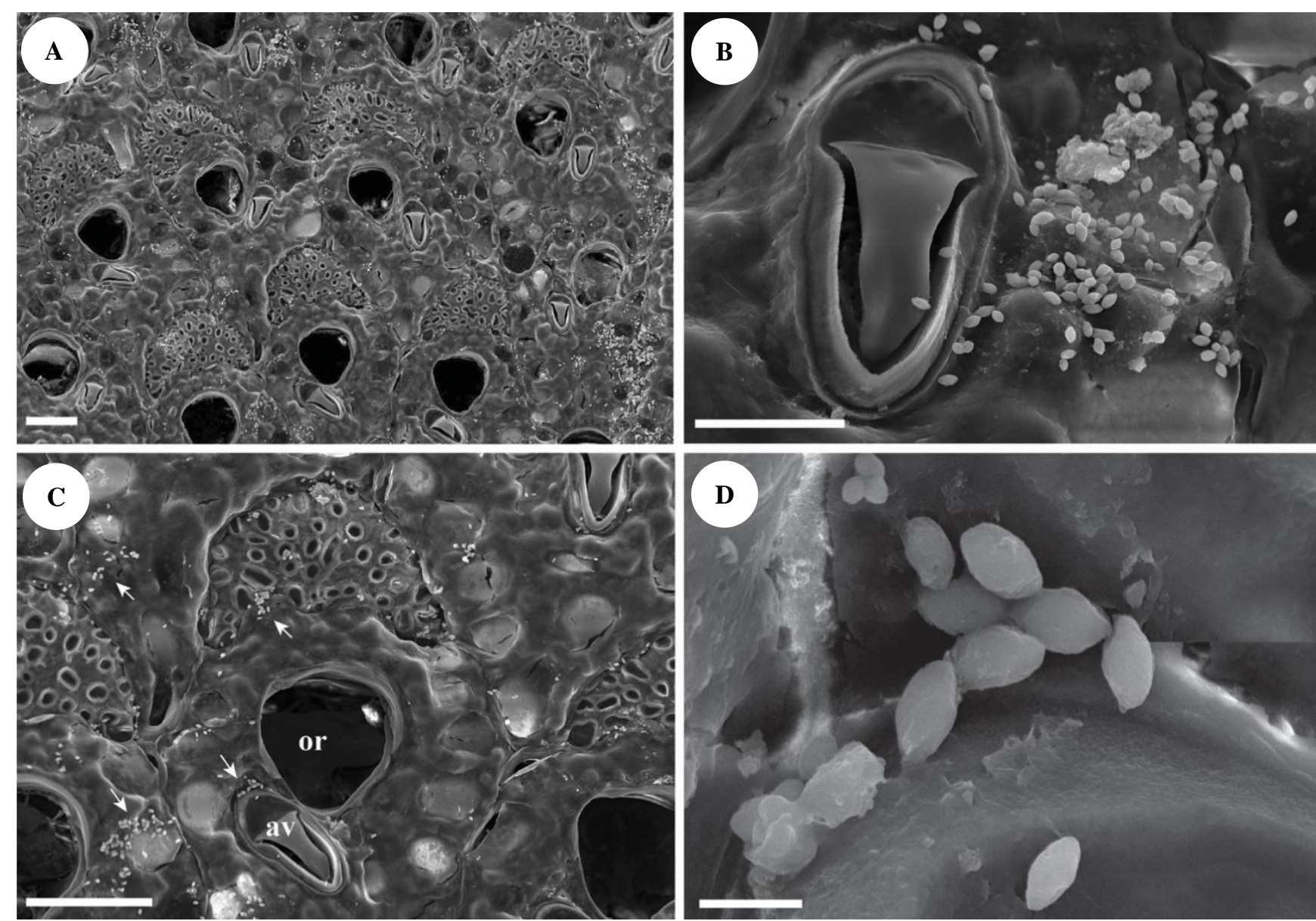

Figure 3. Electron micrograph of colony Pleurocodonellina sp. isolate TAB03-6. A. autozooids of the colony Pleurocodonellina sp. with orifice (or) and avicularia (av) that were covered by operculum, B. Avicularia are covered by operculum, showed lack of bacteria colonization and bacteria were shown on the lateral part of avicularia, C. Single zooid with the presence of bacterial colonization on the surface of colony that is marked by red arrows, $\mathrm{D}$. Close-up of bacteria colonization on the proximal part of avicularia. Scale bar: $\mathrm{A}=$ $100 \mu \mathrm{m} ; \mathrm{B}=35 \mu \mathrm{m} ; \mathrm{C}=100 \mu \mathrm{m} ; \mathrm{D}=5 \mu \mathrm{m}$ 


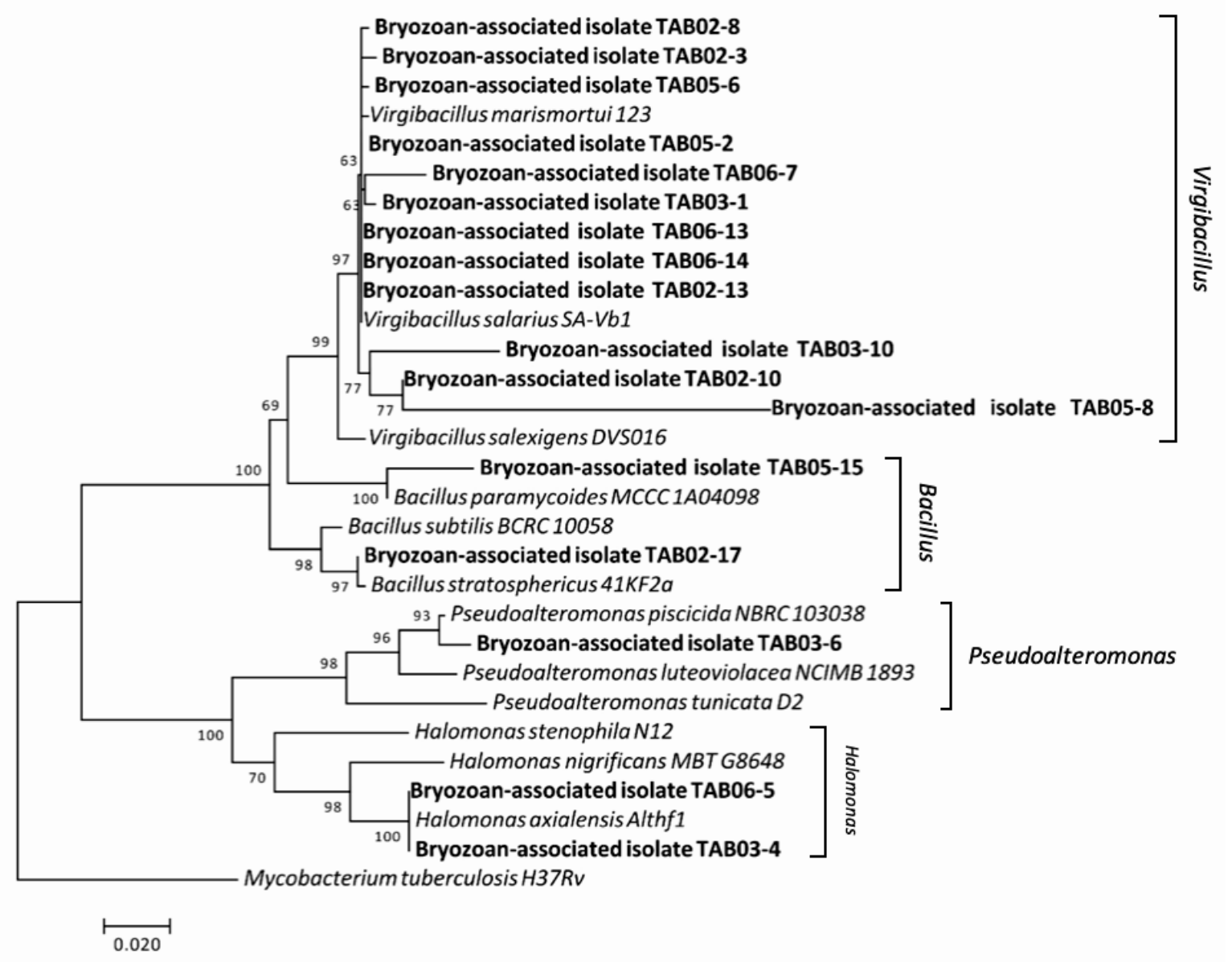

Figure 4. Neighbor-joining tree constructed with Tamura-Nei model from 16S rRNA gene sequences showing the phylogenetic relationships of strains from this study to closely related species and some other selected strains. Non-parametric bootstrapping analysis (1000 datasets) was conducted

\section{Discussion}

In this study, four colonies of species Pleurocodonellina sp. were found in intertidal zones (depth 1-3 m). From what is known of other tropical regions (Almeida et al. 2015; Almeida et al. 2017; Almeida et al. 2018), it is likely that the majority of the hard-shore and coral-associated intertidal zones of the Java Sea would have many more bryozoan species including genus Pleurocodonellina. The study of potential bacteria isolated from bryozoans is not as comprehensive as for other marine organisms such as sponges (Asagabaldan et al. 2017), corals (Sibero et al. 2019) and ascidians (Ayuningrum et al. 2019) in the Java Sea; indeed, no information exists. Teluk Awur is located in the central Java Sea, the latter presenting a wide variety of associated rich organismal communities. The discovery of four bryozoan colonies in present study is indicative of the new source of potential-bacteria hosts to be expected when shallow coastal areas are more fully explored.

As far as we know, among the specimens collected in this study, they had not been examined previously for bacterial coverage. Therefore, scanning electron microscopic studies were firstly conducted with this bryozoan species sampled from the Java Sea. In comparison with the study of bryozoan surfaces, the bryozoans Pleurocodonellina sp., which were collected in Teluk Awur, displayed a thin microbial coverage, whereas the surface of bryozoan Cryptosula pallasiana, Schizobrachiella sanguinea, and Schizotheca serratimargo, which were collected from Mediterranean Sea, displayed a bacterial biofilm (Heindl et al. 2010). Some reports from Nogales et al. (2011) and Crain et al. (2008) analyzed that the effect of anthropogenic activities on microbial communities is complex, it could be addictive, synergistic, or antagonistic. These effects could impair the bryozoans fitness, therefore affecting colonization on their surfaces.

In this study, members of the genera Virgibacillus, Halomonas, Bacillus, and Pseudoalteromonas were found to be associated with bryozoan Pleurocodonellina sp. and all type strains related of the genera validly described species originates from marine habitats. Previous studies on bacteria associated with the bryozoans showed similar results (Pukall et al. 2001; Heindl et al. 2010; 2012), which is genus Pseudoalteromonas was predominantly obtained, whereas only one strain $P$. piscicida TAB03-6 has been isolated in this study. On the other hand, bacterial isolates 
from bryozoan Membranipora membranacea were also found genus Halomonas (Heindl et al. 2012), which was similar to our results. Genus Bacillus was also dominantly associated with bryozoan Flustra foliacea (Heindl et al. 2010). Genus Virgibacillus, which is the most abundant genus in this study, is firstly added as bacteria associated with bryozoan, since there are no records from previous studies. All 12 strains of Virgibacillus-related isolates in this study were also validly marine origin bacteria. Compared to this results, the genus Virgibacillus is commonly associated in other marine organisms in Java Sea such as; corals (Kristiana et al. 2017; Ayuningrum et al. 2017) and ascidians (Ayuningrum et al. 2019).

The antibacterial activities of practically all active isolates $(30 \%)$ were directed against infectious MDR bacteria. Only five isolates displayed inhibitory effect on both Gram-positive and Gram-negative bacteria. These antagonistic interactions between marine bacteria and infectious human bacteria might be an important aspect in discovering new source of pharmaceutical agents. In the previous study, Ayuningrum et al. (2019) isolated similar bacteria (Virgibacillus, Pseudoalteromonas, Bacillus, and Halomonas comprising $56 \%$ of all isolates) from ascidians and tested them against different human pathogen bacteria (B. cereus, B. megaterium, E. coli, ESBL, and Micrococcus luteus). In this case, the authors discovered compound isatin that isolated from genus Pseudoalteromonas, since their best activities against all indicator organisms, which was similar to our results. Comparable studies of marine bacteria from Indonesia sites also showed strain-specific antibacterial patterns against MDR bacteria, which were isolated from nudibranch (Kristiana et al. 2019).

Marine microorganisms play a major role among the producers of natural products from marine sources (Blunt et al. 2010). Moreover, all bacterial genera related to those found in this study were reported as antimicrobial agents. Such products have been reported, such as marine Pseudoalteromonas (Bowmann 2007; Offret et al. 2016), Halomonas (Bitzer et al. 2006), Bacillus (Mondol et al. 2013; Mohan et al. 2016), and Virgibacillus (Arunachalam et al. 2013). Since antibacterial features had been published for all members of related genera from this study, the diversity of active bacteria found may not be surprising. Nevertheless, the production of secondary metabolites could differ at the strain level, but need to be studied by further experiments.

In conclusion, the bacteria able to colonize bryozoan Pleurocodonelina sp, affiliated to the genera Virgibacillus, Pseudoalteromonas, Halomonas, and Bacillus. Our preliminary data has demonstrated that bryozoan provides a rich source of bacteria with antimicrobial activities against MDR bacteria. Our study also added the genus Virgibacillus as bacteria associated with bryozoan, since there were no reports of this genus isolated from bryozoan. These results may lead to further investigations of discovering the potential bacteria and interactions between macro- and microorganisms since the study of associated bacteria in bryozoan are still scarce.

\section{ACKNOWLEDGEMENTS}

The samples were collected legally by the permission from the Local Government of Jepara, Central Java Province, Indonesia. We thank Medical Microbiology Laboratory of Dr. Kariadi Hospital, Semarang, Central Java for provision of the MDR strains. This work was supported by PMDSU (Master Program of Education Leading to Doctoral Degree for Excellent Graduates) scholarship from the Ministry of Research and Higher Education, Indonesia.

\section{REFERENCES}

Almeida ACS, Alves O, Peso-Aguiar M, Dominguez J, Souza FBC. 2015. Gymnolaemata bryozoans of Bahia State, Brazil. Mar Biodiv Rec 8e: 120. DOI: $10.1017 /$ S1755267215000743

Almeida ACS, Souza FBC, Farias J, Alves OFS, Vieira LM. 2018. Bryozoa on disarticulated bivalve shells from Todos os Santos Bay, northeastern Brazil, with the description of two new species. Zootaxa 4434 (3): 401-428.

Almeida ACS, Souza FBC, Menegola C, Vieira LM. 2017. Diversity of marine bryozoans inhabiting demosponges in Northeastern Brazil. Zootaxa 4290 (2): 281-323.

Anthoni U, Nielsen PH, Pereira M, Christophersen C. 1990. Bryozoan secondary metabolites: A chemotaxonomical challenge. Comp Biochem Physiol B Biochem Mol Biol 96: 431-437.

Arunachalam K, Amirtham JAR. 2013. Antioxidant potential and biochemical evaluation of metabolites from the marine bacteria Virgibacillus sp. associated with the sponge Callyspongia diffusa. Free Radic Antiox 3(1): 47-51.

Asagabaldan MA, Ayuningrum D, Kristiana R, Sabdono A, Radjasa OK, Trianto A. 2017. Identification and antibacterial activity of bacteria isolated from marine sponge Haliclona (Reniera) sp. against multidrug resistant human pathogen. IOP Conf Ser Earth Environ Sci 55: 012019. DOI: 10.1088/1755-1315/55/1/012019

Ayuningrum D, Kristiana R, Asagabaldan MA, Sabdono A, Radjasa OK, Nuryadi H. 2017. Isolation, characterisation and antagonistic activity of bacteria symbionts hard coral Pavona sp. isolated from Panjang Island, Jepara against infectious multi-drug resistant (MDR) bacteria. IOP Conf Ser Earth Environ Sci 55: 012029. DOI: 10.1088/17551315/55/1/012029

Ayuningrum D, Liu Y, Riyanti, Sibero MT, Kristiana R, Asagabaldan MA, Wuisan ZG, Trianto A, Radjasa OK, Sabdono A, Schaeberle TF. 2019. Tunicate-associated bacteria show great potential for the discovery of antimicrobial compounds. PLOS One 14(3): 1-14. DOI: 10.1371/journal.pone.0213797

Bitzer J, Grosse T, Wang L, Lang S, Beil WAZ. 2006. New aminophenoxazinones from a marine Halomonas sp.: fermentation, structure elucidation, and biological activity. J Antibiot 59 (2): 7.

Blunt JW, Copp BR, Keyzers RA, Munro MHG, Prinsep MR. 2015. Marine natural products. Nat Prod Rep 32: 116-211.

Blunt JW, Copp BR, Munro MHG, Northcote PT, Prinsep MR. 2010. Marine natural products. Nat Prod Rep 27: 165.

Bowman JP. 2007. Bioactive compound synthetic capacity and ecological significance of marine bacterial Genus Pseudoalteromonas. Mar Drugs 5: 220-241.

CDC. 2013. Antibiotic resistance threats in the United States, 2013. Current 114.

Crain CM, Kroeker K, Halpern B. 2008. Interactive and cumulative effects of multiple human stressors in marine systems. Ecol Lett 11: 1304-1315.

Davidson SK, Allen SW, Lim GE, Anderson CM, Haygood MG. 2001. Evidence for the Biosynthesis of Bryostatins by the Bacterial Symbiont "Candidatus Endobugula sertula" of the Bryozoan Bugula neritina. Applied and Environmental Microbiology 67: 4531-4537.

Di Martino E, Taylor PD. 2018. Early Pleistocene and Holocene bryozoans from Indonesia. Zootaxa 4419: 1-70.

Di Martino E, Taylor PD. 2015. Miocene Bryozoa from East Kalimantan, Indonesia. Part II: "Ascophoran" Cheilostomata. Scripta Geologica 148: 1-142. 
Di Martino E, Taylor PD, Johnson KG. 2015. Bryozoan diversity in the miocene of the Kutai Basin, East Kalimantan, Indonesia. Palaios 30: 109-115.

Guiton PS, Hung CS, Hancock LE, Caparon MG, Hultgren SJ. 2010 Enterococcal biofilm formation and virulence in an optimized murine model of foreign body-associated urinary tract infections. Infect Immun 78: 4166-4175.

Heindl H, Wiese J, Thiel V, Imhoff JF. 2010. Phylogenetic diversity and antimicrobial activities of bryozoan-associated bacteria isolated from Mediterranean and Baltic Sea habitats. Syst Appl Microbiol 33: 94 104.

Heindl H, Thiel V, Wiese J, Imhoff JF. 2012. Bacterial isolates from the bryozoan Membranipora membranacea: Influence of culture media on isolation and antimicrobial activity. Intl Microbiol 15:17-32.

Kerr KG, Snelling AM. 2009. Pseudomonas aeruginosa: a formidable and ever-present adversary. J Hosp Infect 73: 338-344

König GM, Kehraus S, Seibert SF, Abdel-Lateef A, Müller D. 2006 Natural products from marine organisms and their associated microbes. ChemBioChem 7: 229-238

Kristiana R, Sibero MT, Farisa MY, Ayuningrum D, Dirgantara D, Hanafi M, Radjasa OK, Sabdono A, Trianto A. 2019. Antibacterial potential of nudibranch-associated bacteria from Saparua and Nusa Laut Islands, Indonesia. Biodiversitas 20 (7): 1811-1819.

Kristiana R, Ayuningrum D, Asagabaldan MA, Nuryadi H, Sabdono A Radjasa OK. 2017. Isolation and partial characterization of bacteria activity associated with gorgonian Euplexaura sp. against methicillinresistant Staphylococcus aureus (MRSA). IOP Conference Series: Earth and Environmental Science: 55: 012056. DOI: 10.1088/1755$1315 / 55 / 1 / 012056$

Lane DL. 1991. 16S/23S rRNA sequencing. In: Stackebrandt E. (ed.) Nucleic acid Techniques in Bacterial Systematics. Wiley, New York.

Lister PD, Wolter DJ, Hanson ND. 2009. Antibacterial-resistant Pseudomonas aeruginosa: Clinical impact and complex regulation of chromosomally encoded resistance mechanisms. Clin Microbiol Rev 22: 582-610

Lopanik N, Gustafson KR, Lindquist N. 2004. Structure of bryostatin 20 A symbiont-produced chemical defense for larvae of the host bryozoan, Bugula neritina. J Nat Prod 67: 1412-1414.

Madigan MT, Martinko JM, Bender KS, Buckley DH, Stahl DA. 2015 Brock biology of microorganisms. 14th ed. Pearson, Boston.

Massard JA, Geimer G. 2008. Global diversity of bryozoans (Bryozoa or Ectoprocta) in freshwater. Hydrobiologia 595: 93-99.

Mauldin PD, Salgado CD, Hansen IS, Durup DT, Bosso JA. 2010 Attributable hospital cost and length of stay associated with healthcare-associated infections caused by antibiotic-resistant gramnegative bacteria. Antimicrob Agents Chemother 54:109-115.

Mohan G, Thipparamalai TAK, Ramasamy B. 2016. Antimicrobial activities of secondary metabolites and phylogenetic study of sponge endosymbiotic bacteria, Bacillus sp. at Agatti Island, Lakshadweep Archipelago. Biotechnol Rep 11: 44-52.
Mondol MA, Shin HJ, Islam MT. 2013. Diversity of secondary metabolites from marine Bacillus species: chemistry and biological activity. Mar Drugs 11(8): 2846-72.

Nogales B, Lanfranconi MP, Piña-Villalonga JM, Bosch R. 2011. Anthropogenic perturbations in marine microbial communities. FEMS Microbiol Rev 358: 275-298.

Offret C, Desriac F, Le Chevalier P, Mounier J, Jegou C, Fleury Y. 2016. Spotlight on antimicrobial metabolites from the marine bacteria Pseudoalteromonas: Chemodiversity and ecological significance. Mar Drugs 14(7). DOI: 10.3390/md14070129

Peters L, König GM, Terlau H, Wright AD. 2002. Four new bromotryptamine derivatives from the marine bryozoan Flustra foliacea. J Nat Prod 65: 1633-1637.

Pettit GR, Herald CL, Doubek DL, Herald DL, Arnold E, Clardy J. 1982. Isolation and Structure of Bryostatin 1. J Amer Chem Soc 104: 68466848.

Pukall R, Kramer I, Rohde M, Stackebrandt E. 2001. Microbial diversity of cultivatable bacteria associated with the North Sea bryozoan Flustra foliacea. Systematic and Applied Microbiology 24: 623-633.

Ryland JS. 2005. Bryozoa: an introductory overview. In: Woess E (ed)Moostiere (Bryozoa). Denisia 16: 9-20

Sabuda DM, Laupland K, Pitout J, Dalton B, Rabin H, Louie T, Conly J. 2008. Utilization of colistin for treatment of multidrug-resistant Pseudomonas aeruginosa. Canadian J Infect Dis Med Microbiol 19: 413-418

Schaufelberger DE, Koleck MP, Beutler JA, Vatakis AM, Alvarado AB, Andrews P, Marzo LV, Muschik GM, Roach J, Ross JT. 1991. The large-Scale isolation of bryostatin 1 from Bugula neritina following current good manufacturing practices. J Nat Prod 54: 1265-1270.

Sharp JH, Winson MK, Porter JS. 2007. Bryozoan metabolites: An ecological perspective. Nat Prod Rep 24: 659-673.

Sibero MT, Bachtiarini TU, Trianto A, Lupita AH, Sari DP, Igarashi Y, Harunari E, Sharma AR, Radjasa OK, Sabdono A. 2019. Characterization of a yellow-pigmented coral-associated bacterium exhibiting antibacterial activity against Multidrug-Resistant (MDR) Organism. Egyptian J Aquat Res 45(1): 81-87.

Tamura K, Dudley J, Nei M, Kumar S. 2007. MEGA4: Molecular Evolutionary Genetics Analysis (MEGA) software version 4.0 Molecular Biology Evolution 24: 1596-9.

Thakur NL, Thakur AN, Müller WEG. 2005. Marine natural products drug discovery. Biotechnology 4: 471-477

Tumbarello M, Repetto E, Trecarichi EM, Bernardini C. 2011. Multidrugresistant Pseudomonas aeruginosa bloodstream infections: risk factors and mortality. Epidemiol Infect 139: 1740-1749.

Walls JT, Blackman AJ, Ritz DA. 1995. Localisation of the amathamide alkaloids in surface bacteria of Amathia wilsoni Kirkpatrick, 1888 (Bryozoa: Ctenostomata). Hydrobiologia 297: 163-172.

Yu HB, Yang F, Li YY, Gan JH, Jiao WH, Lin HW. 2015. Cytotoxic bryostatin derivatives from the South China sea bryozoan Bugula neritina. J Nat Prod 78: 1169-1173. 